M. I. Fedorovska ${ }^{1}$, N. P. Polovko², V. O. Grudko²

${ }^{1}$ Ivano-Frankivsk National Medical University

${ }^{2}$ National University of Pharmacy

\title{
Development of methods for identification and quantitative determination of active substances in the medicated cosmetic cream for use in trichology
}

To prevent and treat androgenic alopecia (AA) a medicated cosmetic cream (MCC) with the saw palmetto extract and the Sophora japonica tincture has been developed. The introduction of MCC in production requires its standardization and development of its quality control methods.

Aim. To determine the qualitative composition and quantitative content of biologically active substances (BAS) in MCC for prevention and complex treatment of AA.

Materials and methods. The study object was the experimental MCC with the saw palmetto extract and the Sophora japonica tincture. The qualitative reactions and the method of adsorption spectrometry (MAS) were proposed for BAS identification and quantitative determination.

Results and discussion. During the study flavonoids and phytosterols were identified. The content of flavonoids calculated with reference to rutin was determined using MAS, it was $1.85 \mathrm{mg} / \mathrm{g}$ of MCC. The quantitative content of the amount of triglycerides and phytosterols calculated with reference to $\beta$-amirine was $3.59 \mathrm{mg} / \mathrm{g}$ of MCC.

Conclusions. The qualitative reactions have been chosen to identify flavonoids for the Sophora japonica tincture and phytosterols for the saw palmetto extract; the conditions for identification and quantitative determination of BAS by MAS have been proposed. The methods developed will be used in the draft of Quality Control Methods (QCM) for MCC for prevention and complex treatment of AA.

Key words: androgenic alopecia; cream; chemical analysis; quality parameters

М. І. Федоровська, Н. П. Половко, В. О. Грудько

Розробка методів ідентифікації та кількісного визначення діючих речовин лікувально-косметичного крему, призначеного для застосування в трихології

Для профрілактики та лікування андрогенної алопеції розроблено лікувально-косметичний крем (ЛКК) з екстрактом плодів пальми сабаль та настойкою софори японської. Впровадження у виробництво ЛКК вимагає його стандартизації і відповідно розробки методик контролю якості.

Мета роботи - визначення якісного складу та кількісного вмісту біологічно активних речовин (БАР) у ЛКК, призначеному для профрілактики і підтримуючої терапії АА.

Матеріали та методи. Об'єктом дослідження є експериментальний лікувально-косметичний крем з сухим екстрактом пальми сабаль та настойкою софори японської. Для ідентифікації та кількісного визначення БАР запропоновані якісні реакції та метод адсорбційної спектрофотометрії (АСФМ).

Результати та їх обговорення. У ході дослідження ідентифіковані флавоноїди та фрітостероли. Методом АСФМ визначено вміст фрлавоноїдів у перерахунку на рутин, який становить 1,85 мг/г препарату. Кількісний вміст суми триперпеноїдів та фрітостеролів у перерахунку на $\beta$-амірин становить 3,59 мг/г препарату.

Висновки. Обрані якісні реакції на флавоноїди для визначення настойки софори японської та на фітостероли - для екстракту плодів пальми сабаль; запропоновані умови ідентифікації та кількісного визначення БАР методом АСФМ. Розроблені методики покладені в основу проекту МКЯ на ЛКК для профілактики і підтримуючої терапії AA.

Ключові слова: андрогенна алопеція; крем; хімічний аналіз; показники якості

М. И. Федоровская, Н. П. Половко, В. А. Грудько

Разработка методов идентификации и количественного определения действующих веществ лечебно-косметического крема, предназначенного для применения в трихологии

Для профилактики и лечения андрогенной алопеции разработан лечебно-косметический крем (ЛКК) с экстрактом плодов пальмы сабаль и настойкой софоры японской. Внедрение в производство ЛКК требует его стандартизации и соответственно разработки методик контроля качества.

Цель работы - определение качественного состава и количественного содержания биологически активных веществ (БАВ) в ЛКК, предназначенном для профилактики и поддерживающей терапии АА.

Материалы и методы. Объектом исследования является экспериментальный лечебно-косметический крем с сухим экстрактом пальмы сабаль и настойкой софоры японской. Для идентификации и количественного определения БАВ предложены качественные реакции и метод адсорбционной спектрофотометрии (АСФМ). 
Результаты и их обсуждение. В ходе исследования идентифицированы фрлавоноиды и фитостеролы. Методом АСФМ определено содержание флавоноидов в пересчете на рутин, которое составляет 1,85 мг/г препарата. Количественное содержание суммы тритерпеноидов и фитостеролов в пересчете на $\beta$-амирин составляет 3,59 мг/г препарата.

Выводы. Избраны качественные реакции на флавоноиды для определения настойки софоры японской и фритостеролы - для экстракта плодов пальмы сабаль; предложены условия идентификации и количественного определения БАВ методом АСФМ. Разработанные методики положены в основу проекта МКЯ на ЛКК для просрилактики и поддерживающей терапии АА.

Ключевые слова: андрогенная алопеция; крем; химический анализ; показатели качества

Androgenic alopecia (AA) is a common form of genetically determined baldness caused by the action of androgens on the hair follicles (HF). Medicinal and parapharmaceutical remedies for prevention and therapy of AA contain synthetic and natural active substances that enhance the skin circulation (minoxidil, Capsicum annum tincture, sponge powder, rutin, escin, esculetin, etc.), inhibit 5- $\alpha$-reductase (finasteride, $\beta$-sitosterol and other phytosterols, lauric acid) and block androgen receptors ( $\beta$-sitosterol, fluridil) $[1,2]$.

Considering the necessary pharmacological action and the needs of the pharmaceutical market a medicated cosmetic cream (MCC) with the saw palmetto extract and the Sophora japonica tincture for prevention and complex treatment of AA was developed [3]. Saw palmetto (Serenoa repens Small) fruits contain phytosterols, fatty acids, esterified sterols and their glycosides [4]. Biologically active substances (BAS) of saw palmetto suppress 5 - $\alpha$-reductase enzyme that is responsible for formation of the active hormone - dihydrotestosterone (DHT) in the blood. Interacting with androgen receptors, DHT causes abnormal microcirculation and HF miniaturization with the subsequent hair loss. Phytosterols also block approximately $50 \%$ of DHT sensitive receptor and prevent its binding to the nuclei of the triggered cells [5]. Sophora japonica fruits contain a significant amount of rutin (up to $30 \%$ ), as well as kaempherol, quercetin and other flavonoids. BAS of Sophora japonica have the capillary protective effect and stimulate the blood circulation in HF [6].

The introduction of MCC in production requires its standardization and development of its quality control methods [7]. Development of methods for identification and quantitative determination of the saw palmetto extract and the Sophora japonica tincture in the MCC composition allow providing its quality during production, application and storage.

The aim of the work is to determine the qualitative composition and quantitative content of BAS in MCC for prevention and complex treatment of AA.

\section{Materials and methods}

The study object was MCC with the saw palmetto extract and the Sophora japonica tincture. For standardization the numerical indexes were determined in 5 batches of MCC. Identification and quantitative determination of the herbal substances were carried out considering their active ingredients, namely flavonoids (for the Sophora japonica tincture) and phytosterols (for the saw palmetto extract) $[4,8]$.
The qualitative reactions and the method of adsorption spectrometry (MAS) were proposed for BAS identification.

Identification of BAS of the Sophora japonica tincture. Weigh approximately $2 \mathrm{~g}$ of MCC into a weighing bottle, add $6 \mathrm{ml}$ of $70 \%$ ethanol and mix thoroughly. Filter the emulsion obtained through a paper filter. Add 2-3 drops of iron (III) chloride solution $R 1$ to $2 \mathrm{ml}$ of the resulting filtrate. A black and green color should appear.

Add 3-4 drops of dilute solution of sodium hydroxide to $2 \mathrm{ml}$ of the filtrate previously obtained. An intense yellow color should appear.

MAS. To determine the absorption spectrum of flavonoids in the wavelength range of $390-470 \mathrm{~nm}$ the solution is prepared as indicated in the section "Quantitative determination of flavonoids".

Identification of BAS of the saw palmetto extract. In order to identify the amount of triterpenoids and phytosterols the method of the State Pharmacopoeia of Ukraine ( $\mathrm{SPhU}$ ) proposed to determine the amount of nonsaponified substances (SPhU 2.5.7) was used [9].

Place $0.1 \mathrm{~g}$ of MCC in a $50 \mathrm{ml}$ round-bottom flask, add $10 \mathrm{ml}$ of $2 \mathrm{M}$ potassium hydroxide alcoholic solution and boil on a water bath with a reflux condenser for one hour. Cool the solution obtained, then transfer it quantitatively to a separating funnel with $30 \mathrm{ml}$ of water $R$ previously added. Stir the solution, add $15 \mathrm{ml}$ of chloroform $R$, shake thoroughly for $2 \mathrm{~min}$ and allow the layers to stratify. Separate the chloroform layer and filter in an evaporation cup through a paper filter containing $2 \mathrm{~g}$ of anhydrous sodium sulfate, then leave the cup in the hood until the solvent is completely evaporated. Dissolve the residue in $10 \mathrm{ml}$ of ethyl alcohol $R$. Transfer $2 \mathrm{ml}$ of the resulting alcoholic solution to a dry test tube, add several crystals of vanillin, shake the test tube to dissolve the substances, then add $2 \mathrm{ml}$ of sulfuric acid $R$ cautiously down the sides of the tube without stirring. On the border of two layers a yellow-green ring should appear, after a while it gradually should become red-purple.

MAS. To determine the absorption spectrum of phytosterols in the wavelength range of $230-400 \mathrm{~nm}$ the solution is prepared as indicated in the section "Quantitative determination of the amount of steroid compounds".

The quantitative determination of the amount of flavonoids and steroid compounds was carried out using MAS:

According to the method of flavonoid determination developed. Place approximately $0.5 \mathrm{~g}$ of MCC (accurate weight) in a $50 \mathrm{ml}$ flask, add $0.5 \mathrm{ml}$ of $5 \mathrm{~g} / \mathrm{l}$ solu- 
tion of hexamethylenetetramine $R, 1 \mathrm{ml}$ of hydrochloric acid solution $R 1,15 \mathrm{ml}$ of acetone $R$ and boil on a water bath for $45 \mathrm{~min}$. After cooling filter the solution through a small paper filter into a $25 \mathrm{ml}$ volumetric flask. Wash the flask and the filter with two acetone portions of $5 \mathrm{ml}$ each, dilute to the volume of the solution with the same solvent and mix (Solution A).

Place $20 \mathrm{ml}$ of water in a $100 \mathrm{ml}$ separating funnel, add $20 \mathrm{ml}$ of Solution $A$ and $15 \mathrm{ml}$ of ethyl acetate $R$, mix, then add $2 \mathrm{~g}$ of sodium chloride $R$, shake thoroughly until the complete salt dissolution and allow the layers to stratify. Separate the ethyl acetate layer and repeat the extraction three times with $10 \mathrm{ml}$ of ethyl acetate. Transfer the resulting ethyl acetate extracts quantitatively into a separating funnel and wash with two water portions of $50 \mathrm{ml}$ each. Filter the extract obtained through a paper filter containing $2 \mathrm{~g}$ of anhydrous sodium sulfate in a $50 \mathrm{ml}$ volumetric flask, wash the funnel and the filter with ethyl acetate, dilute to the volume of the solution with the same solvent and mix (Solution B).

Preparation of Test solution. Place $10 \mathrm{ml}$ of Solution $B$ in a $25 \mathrm{ml}$ volumetric flask, add $2 \mathrm{ml}$ of aluminum chloride reagent, dilute to the volume with $5 \%$ solution of acetic acid in $96 \%$ ethyl alcohol and mix.

Preparation of Reference solution. Place $10 \mathrm{ml}$ of Solution $B$ in a $25 \mathrm{ml}$ volumetric flask, dilute to the volume with $5 \%$ solution of acetic acid in $96 \%$ ethyl alcohol and mix.

Place the volumetric flasks in a dark place and in $30 \mathrm{~min}$ determine the optical density using a spectrophotometer at the wavelength of $425 \mathrm{~nm}$ in cuvettes with the layer thickness of $10 \mathrm{~mm}$.

The content of the amount of flavonoids calculated with reference to rutin in $\mathrm{mg}$ per $1 \mathrm{~g}$ of $\mathrm{MCC}$ is calculated by the formula:

$$
X=\frac{A \cdot V_{1} \cdot V_{3} \cdot V_{5} \cdot K \cdot 10}{A_{1 \mathrm{~cm}}^{1 \%} \cdot m_{w} \cdot V_{2} \cdot V_{4}},
$$

where: $A$ - is the optical density of Test solution; $A_{1 \mathrm{~cm}}^{1 \%}-$ is the specific absorption rate of hyperoside (500); $m_{w}-$ is the weight of MCC, $\mathrm{g} ; V_{1}$ - is the volume of Solution $A(25 \mathrm{ml}) ; V_{2}-$ is the volume of the aliquot $(20 \mathrm{ml})$; $V_{3}$ - is the volume of the volumetric flask with the second dilution (50 ml of Solution $B) ; V_{4}$ - is the volume of the second aliquot $(10 \mathrm{ml}) ; V_{5}$ - is the volume of the volumetric flask of Test solution $(25 \mathrm{ml}) ; K$ - is the recalculation coefficient of hyperoside conversion into rutin (1.412).

The amount of steroid compounds. Absorption spectrophotometry (SPhU 2.2.29).

Preparation of Test solution. Place $0.1 \mathrm{~g}$ of MCC in a $50 \mathrm{ml}$ round-bottom flask, add $20 \mathrm{ml}$ of $2 \mathrm{M}$ potassium hydroxide alcoholic solution and boil on a water bath with a reflux condenser for one hour. Cool the solution obtained, then transfer it quantitatively to a $125 \mathrm{ml}$ separating funnel with $50 \mathrm{ml}$ of water $R$ previously added. Stir the solution, add $20 \mathrm{ml}$ of chloroform $R$, shake thoroughly for $2 \mathrm{~min}$ and allow the layers to stratify. Separate the chloroform layer and filter in a $100 \mathrm{ml}$ evaporation cup through a paper filter containing $2 \mathrm{~g}$ of anhydrous sodium sulfate. Repeat the extraction twice with chloroform $R$ portions of $20 \mathrm{ml}$ each filtering the extract through the same filter in the same cup. Wash the filter with two $5 \mathrm{ml}$ portions of chloroform $R$ and leave the cup in the hood until the solvent is completely evaporated.

Add $4 \mathrm{ml}$ of concentrated sulfuric acid $R$ to the dry residue in the evaporation cup, dissolve thoroughly with a glass rod and transfer to a $10 \mathrm{ml}$ volumetric flask using the rod. Wash the cup with two more portions of concentrated sulfuric acid $R$ of 3 and $2 \mathrm{ml}$, transfer the resulting solutions to the same volumetric flask, dilute to the volume of the solution with the same solvent and mix. Measure the optical density using a spectrophotometer at the wavelength of $311 \mathrm{~nm}$ in relation to the compensation solution (concentrated sulfuric acid $R$ ) in cuvettes with the layer thickness of $10 \mathrm{~mm}$.

The content of the amount of steroid compounds calculated with reference to $\beta$-amirin mg per $1 \mathrm{~g}$ of $\mathrm{MCC}$ is calculated by the formula:

$$
X=\frac{A \cdot V_{1} \cdot 10}{A_{1 c m}^{1 \%} \cdot m_{w}},
$$

where: $A$ - is the optical density of Test solution; $A_{1 c m}^{1 \%}-$ is the specific absorption rate of $\beta$-amirin under conditions of the experiment (340); $m_{w}-$ is the weight of MCC, $\mathrm{g}$; $V_{1}$ - is the volume of the volumetric flask $(10 \mathrm{ml})$.

\section{Results and Discussion}

Flavonoids of the Sophora japonica tincture belong to polyphenolic compounds and give a reaction with $\mathrm{Fe}^{3+}$ salts. As a result of the experiment a black-and green color appears.

One of the common reactions to determine flavonoids is the reaction of forming chalcones with a dilute solution of sodium hydroxide. As a result of the experiment an intense yellow color appears.

If the quantitative determination of active substances in a drug is carried out by the method of adsorption spectrophotometry, the same method should be used for their identification. Light absorption of the solution of the mixture of substances is the integral sum of absorption of each component. Related substances have similar chromophores, and therefore, similar absorption spectra, that is why spectrophotometry is often used to determine the amount of compounds of the same chemical group. In this case, the content of the amount of BAS is determined calculating conventionally with reference to one marker standard substance of the group.

It is known when various flavonoids interact with an acidified alcoholic solution of aluminum chloride, a yellow color appears. The SPhU recommends this reaction for the quantitative determination of the amount of flavonoids in different types of the plant raw material [9]. The absorption spectrum of the solution prepared as specified in the section "Quantitative determination of flavonoids" in the range of 390-470 nm should have a maximum at a wavelength of $425-427 \mathrm{~nm}$ (Fig. 1).

When determining the amount of triterpenoids and phytosterols according to the method of the SPhU 2.5.7 the methylene groups of steroid compounds can react with vanillin in the presence of concentrated sulfuric acid $R$ 


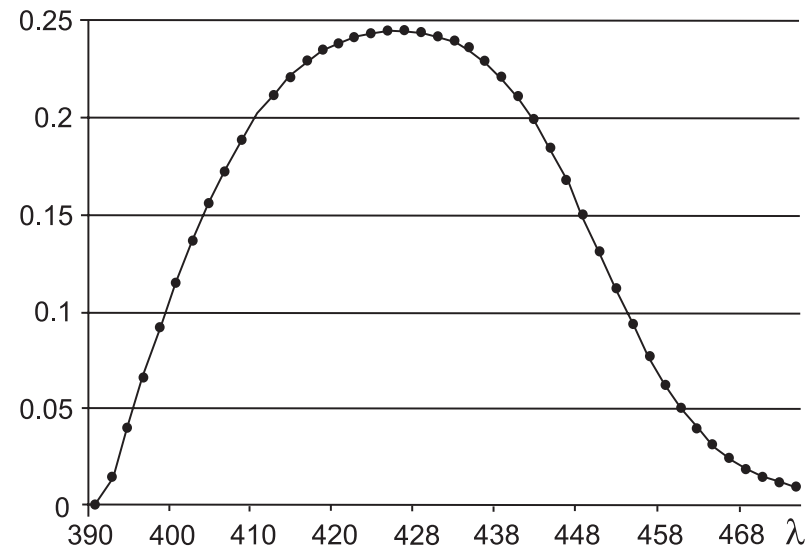

Fig. 1. The adsorption spectrum obtained when determining the amount of flavonoids in the MCC composition studied

to form colored products of condensation. As a result of the experiment, when several vanillin crystals are added to the alcoholic solution of the amount of nonsaponified substances, while sulfuric acid is layered carefully on the border of two layers, a yellow-green ring, which after a while gradually becomes red-purple, appears.

The absorption spectrum of the solution prepared as specified in the section "Quantitative determination of the amount of steroid compounds" in the range of 230$400 \mathrm{~nm}$ should have a maximum at a wavelength of 311 $\pm 2 \mathrm{~nm}$ (Fig. 2).

The results of the quantitative determination

The experimental model batches of MCC were analyzed according to the method of quantitative determination of the amount of flavonoids. The results obtained are presented in Tab. 1 and 2.

The results of the analysis statistically processed are presented in Tab. 2.

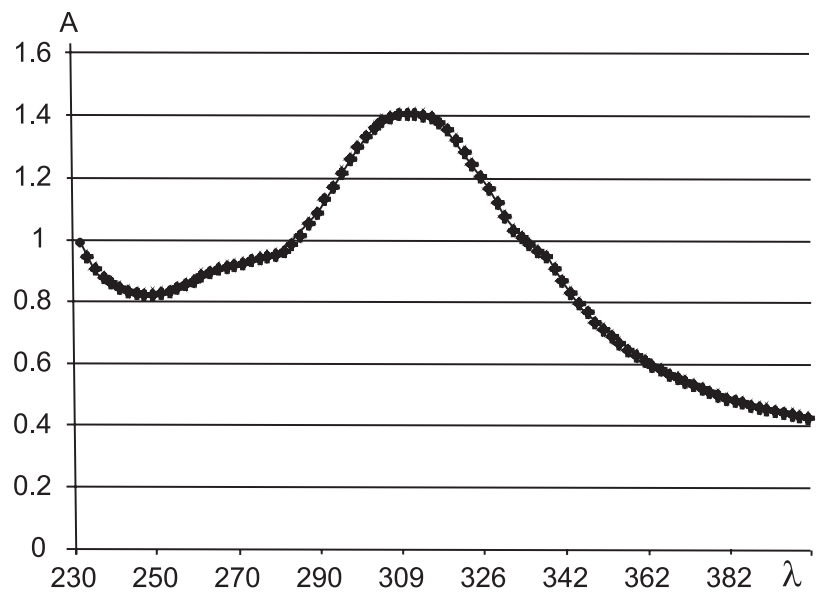

Fig. 2. The adsorption spectrum of the solution of the amount of nonsaponified substances obtained during analysis of MCC in concentrated sulfuric acid $R$

The content of flavonoids calculated with reference to rutin should be $1.48-2.22 \mathrm{mg} / \mathrm{g}$ of $\mathrm{MCC}$.

Literature data suggests that pumpkin seed oil being a part of the cream developed also contains phytosterols, in particular $\beta$-sitosterol [10], which will be also determined together with triterpenoids and phytosterols of the saw palmetto extract. Therefore, the analysis performed is determination of the amount of phytosterols containing in MCC.

According to the method developed for determination of triterpenoids and phytosterols in MCC the experimental batches of the drug were analyzed. The results of the experiments conducted are presented in Tab. 3:

The results of the analysis statistically processed are presented in Tab. 4:

The content of the amount of steroid compounds calculated with reference to $\beta$-amirin should be $2.87-4.31 \mathrm{mg} / \mathrm{g}$ of MCC.

The results of the quantitative determination of the amount of flavonoids

\begin{tabular}{|c|c|c|c|c|c|c|}
\hline The sample code & 1 & 2 & 3 & 4 & 5 & 6 \\
\hline $\mathrm{m}_{\mathrm{i}}$ & 0.5380 & 0.5214 & 0.5073 & 0.5050 & 0.5152 & 0.5196 \\
\hline $\mathrm{A}$ & 0.244 & 0.219 & 0.199 & 0.190 & 0.222 & 0.228 \\
\hline $\mathrm{X}_{\mathrm{mg} / 1 \mathrm{q}}$ & 2.00 & 1.85 & 1.73 & 1.66 & 1.90 & 1.94 \\
\hline
\end{tabular}

Table 2

The statistical processing of the results of the analysis

\begin{tabular}{|c|c|c|c|c|c|c|c|c|c|c|}
\hline $\mathrm{x}, \mathrm{mg}$ & $f$ & $\overline{\bar{x}}$ & $S^{2}$ & $S$ & $S_{\bar{x}}$ & $P, \%$ & $t(P, f)$ & $\Delta x$ & $\Delta \bar{x}$ & $\overline{\bar{\varepsilon}}, \%$ \\
\hline 2.00 & \multirow{6}{*}{5} & \multirow{6}{*}{1.85} & \multirow{6}{*}{0.01671} & \multirow{6}{*}{0.12925} & \multirow{6}{*}{0.05273} & \multirow{6}{*}{95} & \multirow{6}{*}{2.5706} & \multirow{6}{*}{0.13567} & \multirow{6}{*}{0.05539} & \multirow{6}{*}{2.999} \\
\hline 1.85 & & & & & & & & & & \\
\hline 1.73 & & & & & & & & & & \\
\hline 1.66 & & & & & & & & & & \\
\hline 1.90 & & & & & & & & & & \\
\hline 1.94 & & & & & & & & & & \\
\hline
\end{tabular}

Notes: $m$ - is the sample size; $f$ - is the number of degrees of freedom; $\bar{x}$ - is the mean value of the sample analyzed; $S^{2}-$ is dispersion; $S, S_{\bar{x}}-$ is the standard deviation (the separate and mean measurement, respectively); $P$ - is the confidence probability;

$\underline{t}(P, f)$ - is table values of Student's t-test; $\Delta x, \Delta x_{\text {mean }}$ - is the confidence interval (the separate and mean measurement, respectively); $\bar{\varepsilon}, \%$ - is the relative error of the mean measurement, $\%$. 
The results of the quantitative determination of the amount of phytosterols

\begin{tabular}{|c|c|c|c|c|c|c|}
\hline The sample code & 1 & 2 & 3 & 4 & 5 & 6 \\
\hline$m_{i}$ & 0.1065 & 0.1034 & 0.0998 & 0.1012 & 0.0973 & 0.0986 \\
\hline $\mathrm{A}$ & 1.396 & 1.244 & 1.093 & 1.294 & 1.154 & 1.234 \\
\hline $\mathrm{X}_{\mathrm{mq} / 1 \mathrm{q}}$ & 3.85 & 3.54 & 3.22 & 3.76 & 3.49 & 3.68 \\
\hline
\end{tabular}

Table 4

The statistical processing of the results of the analysis

\begin{tabular}{|c|c|c|c|c|c|c|c|c|c|c|}
\hline $\mathrm{X}, \mathrm{Mr}$ & $f$ & $x$ & $S^{2}$ & $S$ & $S_{\bar{x}}$ & $P, \%$ & $t(P, f)$ & $\Delta x$ & $\Delta \bar{x}$ & $\bar{\varepsilon}, \%$ \\
\hline 3.85 & \multirow{6}{*}{5} & \multirow{6}{*}{3.59} & \multirow{6}{*}{0.0508} & \multirow{6}{*}{0.25539} & \multirow{6}{*}{0.09201} & \multirow{6}{*}{95} & \multirow{6}{*}{2.5706} & \multirow{6}{*}{0.23657} & \multirow{6}{*}{0.09658} & \multirow{6}{*}{2.69} \\
\hline 3.54 & & & & & & & & & & \\
\hline 3.22 & & & & & & & & & & \\
\hline 3.76 & & & & & & & & & & \\
\hline 3.49 & & & & & & & & & & \\
\hline 3.68 & & & & & & & & & & \\
\hline
\end{tabular}

\section{CONCLUSIONS}

1. The method for identification of the Sophora japonica tincture in the composition of the cream has been developed. This method is in using the complex of chemical reactions and spectral characteristics of the solution prepared for the quantitative determination, and it greatly increases the specificity of the analysis.

2 . The spectrophotometric method for the quantitative determination of the amount of flavonoids calculated with reference to rutin in the composition of the experimental MCC has been developed by the products of interaction with aluminum (III) chloride. The analysis of the experimental batches of MCC has been performed according to the method developed; the metrological characteristics of the mean result have been obtained. It has been shown that the content of flavonoids calculated with reference to rutin is $1.85 \mathrm{mg} / \mathrm{g}$ of MCC. The relative uncertainty of the mean result is $2.99 \%$.

3. Due to the low content (less than $2 \mathrm{mg}$ ) and the possibility of variations in the content of the active substances in the plant raw material it has been proposed to regulate the content of the amount of flavonoids calculated with reference to rutin in the cream developed within $\pm 20 \%$ from 1.48 to $2.22 \mathrm{mg} / \mathrm{g}$ of MCC.

4. Based on the halochromic reaction with concentrated sulfuric acid the spectrophotometric method for identi- fication of phytosterols in the saw palmetto fruit extract after determining the amount of nonsaponified substances from MCC has been developed.

5 . The spectrophotometric method for the quantitative determination of the amount of triterpenoids and phytosterols calculated with reference to $\beta$-amirin in the composition of the MCC nonsaponified residue has been developed based on the halochromic reaction with concentrated sulfuric acid. It has been shown that the content of the amount of triterpenoids and phytosterols calculated with reference to $\beta$-amirine is $3.59 \mathrm{mg} / \mathrm{g}$ of MCC. The relative uncertainty of the mean result is $2.69 \%$.

6 . Due to the low content (less than $2 \mathrm{mg}$ ) and the possibility of variations in the content of the active substances in the plant raw material it has been proposed to regulate the content of the amount of triterpenoids and phytosterols calculated with reference to $\beta$-amirine in the cream developed within $\pm 20 \%$ from 2.87 to $4.31 \mathrm{mg} / \mathrm{g}$ of MCC.

7. The results of the research conducted will be used when developing QCM in the process of introduction of MCC with the saw palmetto extract and the Sophora japonica tincture for prevention and complex treatment of AA into production.

Conflict of Interests: authors have no conflict of interests to declare.

\section{REFERENCES}

1. Гаджигороева, А. Г. Инновационное лечение андрогенетической алопеции / А. Г. Гаджигороева // Cosmomed. - 2012 - № 3. - С. 16-20.

2. Святенко, Т. В. Алопеция : классификации, этиопатогенез, клинические проявления, современные возможности терапии / Т. В. Святенко, Л. А. Андриуца // Medix. Anti-Aging. - 2011. - № 1 (19). - С. 65-69.

3. Федоровська, М. І. Розробка технології крем-маски з рослинними субстанціями для терапії андрогенної алопеції / М. I. Федоровська, Н. П. Половко, Н. С. Леочко // ScienceRise : Pharmac. Sci. - 2017. - № 3. - С. 19-24.

4. Орлова, С. Е. Фитохимический анализ плодов пальмы сабаль / С. Е. Орлова, И. Н. Зилфлкаров // Традиционная медицина. 2011. - № 5. - C. 257-258.

5. Chatterjee, S. Saw palmetto (Serenoa repens) in androgenic alopecia / S. Chatterjee, S. K. Agrawala // Natural Product Radiance. 2003. - Vol. 2, Issue 6. - P. 302-305.

6. Современное состояние и перспективы дальнейшего исследования плодов софоры японской / Л. Г. Ковалева, А. М. Сампиев, М. Р. Хочава, Е. Б. Никифорова // Науч. ведомости Белгород. гос. ун-та. Серия : Медицина. Фармация. - 2012. - № 22 (141). C. $163-170$. 
7. Котов, А. Г. Дослідження з розробки та введення монографій на лікарську рослинну сировину до Державної фармакопеї України / А. Г. Котов // Фармаком. - 2009. - С. 5-19.

8. Галкін, О. Ю. Розробка методик ідентифікації та кількісного визначення флавоноїдів у плодах софори японської (Sорһоra Japonica L.) / О. Ю. Галкін, А. Г. Котов // Фармацевтичний часопис. - 2011. - № 4. - С. 77-81.

9. Державна фармакопея України / Державне підприємство «Український науковий фармакопейний центр якості лікарських засобів». - 2-е вид. - Х. : Український науковий фармакопейний центр якості лікарських засобів, 2014. - Т. 1. - 1127 с.

10. Chemical composition and oxidative stability of roasted and cold pressed pumpkin seed oils / S. Nederal, D. Skevin, K. Kraljic et al. // J. of the American Oil Chemists' Society. - 2012. - Vol. 89, Issue 9. - P. 1763-1770. doi: 10.1007/s11746-012-2076-0

\section{REFERENCES}

1. Gadzhygoroeva, A. G. (2012). Cosmomed, 3, 16-20.

2. Sviatenko, T. V. (2011). Medix. Anti-Aging, 1 (19), 65-69.

3. Fedorovska, M. I., Polovko, N. P., Leochko, N. S. (2017). ScienceRise: Pharmaceutical Science, 3, 19-24.

4. Orlova, S. E., Zilflkarov, I. N. (2011). Traditcyonnaia meditcyna, 5, 257-258.

5. Chatterjee, S., Agrawala, S. K. (2003). Saw palmetto (Serenoa repens) in androgenic alopecia. Natural Product Radiance, 2 (6), $302-305$.

6. Kovaleva, L. G., Sampiev, A. M., Khochava, M. R., Nikifirova, E. B. (2012). Nauchnye vedomosti Belgorodskogo gosudarstvennogo universiteta. Seriia: Meditcyna. Farmatciia, 22 (141), 163-170.

7. Kotov, A. H. (2009). Farmacom, 5, 5-19.

8. Halkin, O. Yu., Kotov, A. H. (2011). Farmatsevtychnyi chasopys, 4, 77-81.

9. Derzhavna farmakopeia Ukrainy. (2014). Kharkiv: Ukrainskyi naukovyi farmakopeinyi tsentr yakosti likarskykh zasobiv, 1, 1127.

10. Neđeral, S., Škevin, D., Kraljić, K., Obranović, M., Papeša, S., Bataljaku, A. (2012). Chemical Composition and Oxidative Stability of Roasted and Cold Pressed Pumpkin Seed Oils. Journal of the American Oil Chemists' Society, 89 (9), 1763-1770. doi: 10.1007/ s11746-012-2076-0

Information about authors:

Fedorovska M. I., Candidate of Pharmacy (Ph.D), associate professor of the Organization and Economics in Pharmacy and Drug Technology Department, Ivano-Frankivsk National Medical University

Polovko N. P., Doctor of Pharmacy (Dr. habil.), professor, head of the Drug Technology Department named after D. P. Salo, National University of Pharmacy

Grudko V. O., associate professor of the Department of Pharmaceutical Chemistry, National University of Pharmacy

Відомості про авторів:

Федоровська М. І., канд. фарм. наук, доцент кафедри організації та економіки фармації і технології ліків, Івано-Франківський національний медичний університет

Половко Н. П., д-р фарм. наук, професор, завідувач кафедри технології ліків імені Д. П. Сала, Національний фармацевтичний університет.

E-mail: polovko.np@gmail.com

Грудько В. О., канд. хім. наук, доцент кафедри фармацевтичної хімії, Національний фармацевтичний університет

Сведения об авторах:

Федоровская М. И., канд. фарм. наук, доцент кафедры организации и экономики фармации и технологии лекарств,

Ивано-Франковский национальный медицинский университет

Половко Н. П., д-р фарм. наук, профессор, заведующая кафедрой технологии лекарств имени Д. П. Сало, Национальный фармацевтический университет.

E-mail: polovko.np@gmail.com

Грудько В. А., канд. фарм. наук, доцент кафедры фармацевтической химии, Национальный фармацевтический университет 